\title{
ANALISIS HUMAN RELIABILITY ASSESSMENT DENGAN METODE HEART (STUDI KASUS PT ABC)
}

\author{
Yusuf Widharto ${ }^{*}$, Derry Iskandari, Denny Nurkertamanda \\ Departemen Teknik Industri, Fakultas Teknik, Universitas Diponegoro, \\ Jl. Prof. Soedarto, SH, Kampus Undip Tembalang, Semarang, Indonesia 50275
}

(Received: January 8, 2018/Accepted: November 30, 2018)

\begin{abstract}
Abstrak
Salah satu usaha yang dapat dilakukan dalam rangka mengurangi angka kecelakaan kerja yang disebabkan oleh human error adalah dengan menggunakan metode yang mengukur kontribusi tenaga kerja terhadap suatu resiko kerja. Metode ini dikenal sebagai Metode Human Reliability Assesment (HRA). Pada kesempatan ini akan digunakan salah satu dari metode HRA yaitu metode Human Error Assessment and Reduction Technique (HEART) yang merupakan metode untuk melakukan kuantifikasi human reliability. Analisis HRA dengan metode HEART ini mengambil tempat di salah satu lini perakitan PT. ABC yang merupakan salah satu perusahaan manfaktur kelas dunia. Pada lini perakitan di PT. ABC ditemukan beberapa task yaitu 7.1, 14.1 dan 16.1 dimana dari hasil analisis dengan menggunakan metode HEART diperoleh nilai 1 untuk Nilai Human Error Probabilitynya. Task tersebut memiliki karakteristik pekerjaan yang kompleks dan membutuhkan tingkat pemahaman dan keterampilan tinggi serta dari hasil EPC'S operator hanya memiliki waktu singkat untuk mendeteksi kegagalan dan tindakan koreksi. Adapun saran untuk task's tersebut adalah: Petugas yang mengerjakan task's tersebut merupakan petugas yang telah terlatih dan telah bertugas/ menyelesaikan tingkatan tugas yang kesulitannya di bawah task's tersebut (dibuktikan dengan matrix skill), Penggunaan APD yang sesuai khususnya bagi task 7.1 dan 14.1 untuk melindungi dari kemungkinan cedera tergores. Pengalokasian tempat yang cukup bagi manuver petugas untuk taks 16.1. Untuk menghindarkan kemungkinan terjadinya kejadian terjepit, selain itu perlu tindakan berkelanjutan khususnya dalam pemantauan HEP misal HEP yang terbesar selanjutnya dikombinasikan dengan metode lain seperti line balancing sehingga didapatkan kondisi Lini Produksi yang nyaman bagi para pekerja
\end{abstract}

Kata kunci: human error; HRA; HEART

\begin{abstract}
Human Reliability Assessment Analysis with HEART Method (Case Study at PT ABC) One of the effort that can be done in order to reduce the number of work accidents caused by human error, is by using a method that measures the contribution of labor to a work risk. This method is known as the Human Reliability Assessment (HRA) Method. On this occasion, one of the HRA methods that will be used, is called the Human error Assessment and Reduction Technique (HEART), it's a method for quantifying human reliability. The HRA analysis using the HEART method takes place in one of PT ABC's assembly line. PT ABC is one of the world-class manufacturing companies. On the assembly line at PT ABC it's found that task 7.1, 14.1 and 16.1 when being analyse using the HEART method obtained a value of 1 for the Value of the Probability Human Error. Those task's has complex job characteristics and requires a high level of understanding and skill, and from the results of the EPC's officer only has a short time to detect failures and implementing corrective actions. The suggestions for the task's are operator who works on the task is suggested a trained officer who has been assigned / completed the task level whose difficulty is under the task's (proven by matrix skills), the use of APD is suitable especially for 7.1 and 14.1 task to protect from possibly scratched, Allocation of sufficient space for officer manuvers for task 16.1 to avoid the possibility of a pinch event, the need for continuous action, especially in HEP monitoring, for example,

*) Penulis Korespondensi. the biggest HEP is then combined with other methods such as line balancing so that the conditions of the Production Line are comfortable for workers.
\end{abstract}

E-mail: yudidito@gmail.com 
Keywords: human error; HRA; HEART

\section{Pendahuluan}

PT ABC merupakan sebuah perusahaan manufaktur yang bergerak pada produksi barang rumah tangga. Berdasarkan hasil wawancara dan hasil peninjauan lapangan di PT. ABC maka diketemukan proporsi kecelakaan kerja yang disebabkan oleh human error. Untuk mengurangi kecelakaan kerja yang di sebabkan oleh human error pada kesempatan kali ini menggunakan metode HEART. Human Reliability Assesment (HRA) berhubungan dengan penilaian potensi kesalahan manusia dalam suatu sistem, dan biasanya terjadi dalam penilaian risiko kuantitatif kerangka. HRA memiliki tiga fungsi dasar, yaitu identifikasi kesalahan manusia, prediksi kesalahan manusia, dan pengurangan kesalahan manusia. Teknik atau pendekatan HRA dibagi menjadi dua kategori, yang menggunakan database, dan yang menggunakan pendapat ahli. (Barry, 1995)

Rangkuman instrumen yang diperhitungkan dapat digunakan untuk dalam sumber bahaya utama HSE dibagi ke dalam 3 kategori yaitu generasi pertama dimana alat-alat ini adalah yang pertama kali dikembangkan untuk membantu penilai risiko memprediksi dan mengkuantifikasikan kemungkinan kesalahan manusia. Generasi kedua dimana dicoba untuk mempertimbangkan konteks dan commission error dalam prediksi kesalahan manusia adapun generasi ketiga berlangsung ketika instrumen - instrumen baru yang dikembangkan berdasarkan alat generasi pertama sebelumnya seperti HEART, dan disebut sebagai metode generasi ketiga.(Bell, 2009) HEART dirancang untuk menjadi metode cepat dan sederhana dalam mengkuantifikasikan risiko kesalahan manusia. Ini adalah metode yang berlaku secara umum di setiap industri yang mengutamakan reliabilitas manusia. Metode ini didasarkan pada sejumlah premis yaitu :

a. Keandalan manusia dasar tergantung pada sifat umum dari tugas yang akan terjadi dilakukan.

b. Dalam kondisi 'sempurna', tingkat keandalan ini cenderung akan dicapai secara konsisten dengan kemungkinan nominal tertentu dalam batas probabilistik.

c. Mengingat bahwa kondisi sempurna dalam segala situasi tidak dapat tercapai maka, keandalan manusia diprediksikan menurun sebagai perpanjangan fungsi sehingga proses identifikasi EPC dapat diaplikasikan (Bell, 2009).

Pada tahun 2012 Wolfgang Preischl melaksanakan sebuah proyek untuk mengumpulkan data keandalan manusia yang berdasarkan kepada pengalaman operasional pada Pembangkit Listrik Tenaga Nuklir di Jerman. Dimana tujuannya adalah untuk mengumpulkan dan melengkapi database (metode THERP). (Wolfgang, 2012). Pada tahun 2013 telah dilakukan Analisa Human Error dengan Metode SHERPA dan HEART pada kecelakaan kerja di PT. XYZ. Dari penelitian tersebut diketahui prediksi human error yang dapat terjadi pada bagian wet area yaitu kelalaian operator dalam menggunakan APD dengan probabilitas sebesar 0,0532 . Prediksi error yang dapat terjadi pada bagian talcum area yaitu kelalaian operator dalam menggunakan APD dan task 1.1 yaitu membersihkan talcum powder yang tumpah dengan probabilitas sebesar 0,038. Sedangkan prediksi error bagian packing area yaitu kelalaian operator dalam menggunakan APD dengan probabilitas sebesar 0,0232.(Tiara, et.all, 2013).

Masih pada tahun 2013 telah dilaksanakan juga penelitian dengan metode HEART untuk menganalisa Tingkat Keandalan Operator Inside Welding dimana hasil penelitian menunjukkan bahwa tingkat keandalan operator pada bagian inside welding sebesar 0,025. Hasil tersebut menunjukkan keandalan yang rendah sehingga perlu dilakukan perbaikan sistem kerja dengan memberikan pelatihan dengan metode on the jobtraining, memberikan fan exhaust pada bagian inside welding, mengganti mesin motor listrik dengan yang baru, serta melakukan maintenance pada mesin secara berkala.(Saida,et.all, 2013).

Pada tahun 2015 dilaksanakan penelitian dengan menggunakan integerasi THERP and HEART, metodologi untuk menyelidiki skenario kecelakaan yang melibatkan kesalahan operator selama perlakuan dosis tingkat tinggi (HDR). Pendekatan yang baru pada penelitian ini adalah adanya tambahan konsep fuzzy dengan tujuan memprioritaskan daftar yang lengkap dari tugas-tugas yang salah yang dapat menyebabkan terjadinya overexposures pada pasien radiologi. Hasil dari penelitian memungkinkan untuk melakukan identifikasi kesalahan manusia sehingga mencapai pemahaman yang lebih baik tentang bahaya kesehatan dalam proses perawatan kesehatan.(Fransesco,et.all, 2014). Tahun 2015 dilaksanakan penelitian Aplikasi Human Reliability Assesssment sebagai upaya untuk peningkatan kualitas produk batik. Pendekatan Human Reliability Assesment yang digunakan adalah Human Error Assesment and Reduction Technique (HEART) dengan kelengkapannya yang terdiri dari HEART Generic Task dan Error Producing Conditions (EPCs). Breakdown task operator dilakukan dengan Hierarchiecal Task Analysis (HTA).(Agus, 2015). Masih pada tahun 2015 dilaksanakan penelitian yang bertujuan untuk mengevaluasi metode penilaian manusia kesalahan dan membandingkan hasil dari teknik HEART dan CREAM untuk memperkenalkan metode 
penilaian kesalahan manusia yang tepat, dan mengenali faktor-faktor yang mempengaruhi terjadinya kesalahan ini. Dari hasil penelitian menyimpulkan bahwa probabilitas tertinggi dari kesalahan yang dihitung berhubungan dengan pemantauan dan kontrol (operator), mengendalikan tanda-tanda peringatan (operator), dan kerjasama dalam memecahkan masalah (supervisor) untuk keduanya teknik. Dengan mempertimbangkan faktor waktu dan biaya, HEART memiliki keunggulan, sementara CREAM lebih baik karena evaluasi ekstensif dan jumlah kesalahan terdeteksi. (Amin, et.all., 2015).

Masih di tahun 2015 penelitian tentang Human Reliability Assessment dengan Metode Human Error Assessment and Reduction Technique pada Operator Stasiun Shroud PT. X dilakukan. (Dian, 2015), Di tahun 2015 metode HEART juga dipakai dalam penelitian yang bertujuan untuk meneliti kesalahan manusia pada unit perakitan rem cakram dan perawatan boogie kereta. Hasil dari penelitian ini menunjukkan bahwa setiap kali tugas dilakukan pada pemeliharaan unit perakitan rem cakram dan set roda, ada kemungkinan kegagalan dan probabilitas ini dipengaruhi oleh satu atau lebih kondisi menghasilkan kesalahan, misalnya, kekurangan waktu, menimpa informasi, pengalaman, dll(Sarbjeet, et.all, 2015)

Pada tahun 2017 metode HEART digunakan pada perusahaan pembangkit listrik Serbia dalam studi kasus kecelakaan kerja pada perbaikan a 10/0.4 kV steel lattice tower "Maričiće", Kuršumlija (jurisdiction of EPCS, ED "Jugoistok", Nis, Serbia).(Evica,et.all, 2017). Masih di tahun 2017 metode HEART digunakan untuk melakukan analisis kesalahan manusia pada pekerjaan penggantian bola Ball Mill di SAG Mill Concentrating (Shofiana, 2015). Di tahun yang sama metode HEART digunakan dalam Penilaian Human Error Probability Studi di Departemen Finishing PT. Eratex Djaja, Tbk. (Riselvia, et.all, 2015). Pada tahun 2017 Weizhong melakukan modifikasi metode HEART dengan FANP untuk melakukan asessemen pada dispatching task untuk kereta kecepatan tinggi. FANP (Fuzzy Analytical Network Process) digunakan untuk menangani masalah interdependensi dan interaksi antara EPC dan ketidakpastian ada dalam penilaian para ahli (Weizhong,et.all, 2017). Pada tahun 2018 metode HEART digunakan untuk menganalisis kecelakaan laut pada kasus kapal yang digrounded (Ludfi, et. All, 2018). Masih pada tahun yang sama metode HEART juga digunakan untuk menganalisis kesalahan manusia yang terkait information security incidents (Mark, et.all, 2018). Berdasarkan penelitian yang telah tersaji di atas maka pada kesempatan kali ini penulis menggunakan metode HEART pada satu lini produksi dari sebuah perusahaan manufaktur yang terdiri dari berbagai stasiun kerja untuk menganalisis human error yang terjadi pada lini produksi tersebut.

\section{Bahan dan Metode}

Langkah awal dalam penelitian ini, yaitu dengan mengidentifikasi masalah yang ada, lalu melakukan pengumpulan data dengan melakukan observasi, wawancara dan berdasarkan data kecelakaan kerja. Kemudian membuat Hierarchical Task Analysis dan melanjutkan ke langkah selanjutnya untuk menentukan generic tasks beserta Human Error Potential (HEP). Kemudian melihat nilai HEP terbesar dan dilanjutkan dengan penentuan Error Producing Conditions serta tidak lupa memberikan skor EPC. Berdasarkan skor EPCs maka dilakukan perhitungan efek error untuk setiap EPCs yang terjadi. Langkah selanjutnya adalah melakukan perhitungan probabilitas human error dengan melakukan perkalian antara human Reliability sesuai generic task yang diperoleh dengan nilai EPC's. Serta langkah terakhir dengan melakukan analisis dan rekomendasi perbaikan

\section{Hasil dan Pembahasan}

Proses produksi PT ABC pada lini perakitan memiliki memiliki 18 operasi dengan 65 subtask. Pada Tabel 1. operasi dilambangkan dengan lambang huruf A. Adapun subtasknya dilambangkan dengan angka mulai dari 1.1 sampai dengan 18.2. Kemungkinan error yang dapat terjadi untuk setiap sub task ditampilkan dalam kolom Possible Error. Setelah kemungkinan kesalahan setiap subtask diketahui, maka langkah selanjutnya adalah melakukan penentuan tipe task dari kemungkinan error yang terjadi yang diperoleh dari tabel HEART Generic Categories. Adapun secara mendetail tipe task dapat dilihat dalam Tabel 2.

\section{Perhitungan Asessed Proportion of Effect dan Human error Probability}

Setelah nilai generic task unreliability ditentukan, maka langkah selanjutnya adalah menentukan nilai Asessed Proportion of Effect dan Human error Probability. Adapun langkah penentuannya adalah sebagai berikut

$$
\begin{aligned}
& \text { Contoh Perhitungan pada Operasi A sub task } 1.1 \\
& \begin{aligned}
\text { a. } & \text { Assesed Effect } \\
& =((\text { Nilai EPC }-1) \times \text { Assesed Proportion of Effect })+1 \\
& =(0,7 \mathrm{x}(1,2-1)+1) \\
& =1,14 \\
\text { b. } & \text { Human Error Probability } \\
& =(\text { Assesed Effect } \mathrm{x} \text { GTT }) \\
& =1,14 \times \mathrm{x} 0,09 \\
& =0,1026 \\
\text { c. } & \text { Human Reliability }=1-\mathrm{HEP} \\
& =1-0,1026 \\
& =0,8974
\end{aligned}
\end{aligned}
$$


Tabel 1. Identifikasi Kegagalan Proses Lini Perakitan

\begin{tabular}{|c|c|c|c|c|c|c|c|}
\hline No & Operasi & Task & Possible Error & No & Operasi & Task & Possible Error \\
\hline \multirow{7}{*}{1} & \multirow{7}{*}{ A } & 1.1 & Tertimpa & \multirow{3}{*}{8} & \multirow{3}{*}{$\mathrm{H}$} & 8.1 & Tertelan, terhirup \\
\hline & & 1.2 & Terjepit & & & 8.2 & Terhirup \\
\hline & & 1.3 & Terjepit & & & 8.3 & \\
\hline & & 1.4 & Terjepit & \multirow{5}{*}{9} & \multirow{5}{*}{ I } & 9.1 & Tertimpa, terjepit \\
\hline & & 1.5 & Terjepit & & & 9.2 & Terjepit \\
\hline & & 1.6 & Terjepit & & & 9.3 & Tertimpa, tergores \\
\hline & & 1.7 & Terjepit & & & 9.4 & Tertimpa, terjepit \\
\hline \multirow{4}{*}{2} & \multirow{4}{*}{ B } & 2.1 & Tertimpa & & & 9.5 & Tertimpa, terjepit \\
\hline & & 2.2 & Tertusuk & \multirow{2}{*}{10} & \multirow{2}{*}{$\mathrm{J}$} & 10.1 & Tergores \\
\hline & & 2.3 & Tergores & & & 10.2 & Tergores \\
\hline & & 2.4 & Terbakar & \multirow{2}{*}{11} & \multirow{2}{*}{$\mathrm{K}$} & 11.1 & \\
\hline \multirow{5}{*}{3} & \multirow{5}{*}{$\mathrm{C}$} & 3.1 & Terjepit & & & 11.2 & \\
\hline & & 3.2 & Tertusuk & \multirow{3}{*}{12} & \multirow{3}{*}{$\mathrm{L}$} & 12.1 & Tersandung \\
\hline & & 3.3 & Terjepit & & & 12.2 & Tertimpa \\
\hline & & 3.4 & Terjepit & & & 12.3 & Tersandung \\
\hline & & 3.5 & Terjepit & \multirow{6}{*}{13} & \multirow{6}{*}{ M } & 13.1 & Tertimpa \\
\hline \multirow{5}{*}{4} & \multirow{5}{*}{$\mathrm{D}$} & 4.1 & Tertusuk & & & 13.2 & Tertimpa, terjepit \\
\hline & & 4.2 & Terjepit & & & 13.3 & Tertimpa, terjepit \\
\hline & & 4.3 & Terjepit & & & 13.4 & Tertimpa \\
\hline & & 4.4 & Tertimpa & & & 13.5 & \\
\hline & & 4.5 & Terjepit & & & 13.6 & Tertimpa \\
\hline \multirow{4}{*}{5} & \multirow{4}{*}{$\mathrm{E}$} & 5.1 & Terjepit & \multirow{3}{*}{14} & \multirow{3}{*}{$\mathrm{N}$} & 14.1 & Tergores \\
\hline & & 5.2 & Tertimpa, tergores & & & 14.2 & Tertimpa, terjepit \\
\hline & & 5.3 & Tertimpa, terjepit & & & 14.3 & Terjepit \\
\hline & & 5.4 & Tergores & \multirow{3}{*}{15} & \multirow{3}{*}{$\mathrm{O}$} & 15.1 & Terjepit \\
\hline \multirow{3}{*}{6} & \multirow{3}{*}{$\mathrm{F}$} & 6.1 & Tertelan, terhirup & & & 15.2 & Terjepit \\
\hline & & 6.2 & Terhirup & & & 15.3 & Terjepit \\
\hline & & 6.3 & & & & 16.1 & Terjepit \\
\hline & & 7.1 & Terjepit, tertusuk & 16 & $\mathrm{P}$ & 16.2 & $\begin{array}{l}\text { Tertimpa, terjepit, } \\
\text { tertusuk, tergores }\end{array}$ \\
\hline & & 7.2 & Terjepit & & & 16.3 & Tertimpa \\
\hline 7 & $\mathrm{G}$ & 7.3 & Tertusuk & 17 & 0 & 17.1 & Terjepit \\
\hline & & 7.4 & Tertusuk & 17 & $Q$ & 17.2 & \\
\hline & & 7.5 & Tertusuk, tergores & 10 & D & 18.1 & \\
\hline & & 7.6 & Terjepit & 18 & $\mathrm{R}$ & 18.2 & \\
\hline
\end{tabular}


Tabel 2. Klasifikasi Tipe Generic Task Jenis Pekerjaan Lini Perakitan

\begin{tabular}{|c|c|c|c|}
\hline No & & Jenis Pekerjaan & $\begin{array}{c}\text { Generic Task } \\
\text { Unreliability }\end{array}$ \\
\hline 1.1 & $\mathrm{D}$ & Pekerjaan cukup sederhana, dilakukan dengan cepat atau membutuhkan sedikit perhatian. & 0.09 \\
\hline 1.2 & $\mathrm{D}$ & Pekerjaan cukup sederhana, dilakukan dengan cepat atau membutuhkan sedikit perhatian. & 0.09 \\
\hline 1.3 & $\mathrm{D}$ & Pekerjaan cukup sederhana, dilakukan dengan cepat atau membutuhkan sedikit perhatian. & 0.09 \\
\hline 1.4 & $\mathrm{D}$ & Pekerjaan cukup sederhana, dilakukan dengan cepat atau membutuhkan sedikit perhatian. & 0.09 \\
\hline 1.5 & $\mathrm{D}$ & Pekerjaan cukup sederhana, dilakukan dengan cepat atau membutuhkan sedikit perhatian. & 0.09 \\
\hline 1.6 & $\mathrm{D}$ & Pekerjaan cukup sederhana, dilakukan dengan cepat atau membutuhkan sedikit perhatian. & 0.09 \\
\hline 1.7 & $\mathrm{D}$ & Pekerjaan cukup sederhana, dilakukan dengan cepat atau membutuhkan sedikit perhatian. & 0.09 \\
\hline 2.1 & $\mathrm{C}$ & Pekerjaan kompleks dan membutuhkan tingkat pemahaman dan keterampilan tinggi & 0.16 \\
\hline 2.2 & $\mathrm{C}$ & Pekerjaan kompleks dan membutuhkan tingkat pemahaman dan keterampilan tinggi & 0.16 \\
\hline 2.3 & $\mathrm{D}$ & Pekerjaan cukup sederhana, dilakukan dengan cepat atau membutuhkan sedikit perhatian. & 0.09 \\
\hline 2.4 & $\mathrm{D}$ & Pekerjaan cukup sederhana, dilakukan dengan cepat atau membutuhkan sedikit perhatian. & 0.09 \\
\hline 3.1 & $\mathrm{D}$ & Pekerjaan cukup sederhana, dilakukan dengan cepat atau membutuhkan sedikit perhatian. & 0.09 \\
\hline 3.2 & $\mathrm{D}$ & Pekerjaan cukup sederhana, dilakukan dengan cepat atau membutuhkan sedikit perhatian. & 0.09 \\
\hline 3.3 & $\mathrm{D}$ & Pekerjaan cukup sederhana, dilakukan dengan cepat atau membutuhkan sedikit perhatian. & 0.09 \\
\hline 3.4 & $\mathrm{D}$ & Pekerjaan cukup sederhana, dilakukan dengan cepat atau membutuhkan sedikit perhatian. & 0.09 \\
\hline 3.5 & $\mathrm{D}$ & Pekerjaan cukup sederhana, dilakukan dengan cepat atau membutuhkan sedikit perhatian. & 0.09 \\
\hline 4.1 & $\mathrm{D}$ & Pekerjaan cukup sederhana, dilakukan dengan cepat atau membutuhkan sedikit perhatian. & 0.09 \\
\hline 4.2 & $\mathrm{D}$ & Pekerjaan cukup sederhana, dilakukan dengan cepat atau membutuhkan sedikit perhatian. & 0.09 \\
\hline 4.3 & $\mathrm{D}$ & Pekerjaan cukup sederhana, dilakukan dengan cepat atau membutuhkan sedikit perhatian. & 0.09 \\
\hline 4.4 & $\mathrm{D}$ & Pekerjaan cukup sederhana, dilakukan dengan cepat atau membutuhkan sedikit perhatian. & 0.09 \\
\hline 4.5 & $\mathrm{D}$ & Pekerjaan cukup sederhana, dilakukan dengan cepat atau membutuhkan sedikit perhatian. & 0.09 \\
\hline 5.1 & $\mathrm{D}$ & Pekerjaan cukup sederhana, dilakukan dengan cepat atau membutuhkan sedikit perhatian. & 0.09 \\
\hline 5.2 & $\mathrm{D}$ & Pekerjaan cukup sederhana, dilakukan dengan cepat atau membutuhkan sedikit perhatian. & 0.09 \\
\hline 5.3 & $\mathrm{D}$ & Pekerjaan cukup sederhana, dilakukan dengan cepat atau membutuhkan sedikit perhatian. & 0.09 \\
\hline 5.4 & $\mathrm{D}$ & Pekerjaan cukup sederhana, dilakukan dengan cepat atau membutuhkan sedikit perhatian. & 0.09 \\
\hline 6.1 & $\mathrm{D}$ & Pekerjaan cukup sederhana, dilakukan dengan cepat atau membutuhkan sedikit perhatian. & 0.09 \\
\hline 6.2 & $\mathrm{D}$ & Pekerjaan cukup sederhana, dilakukan dengan cepat atau membutuhkan sedikit perhatian. & 0.09 \\
\hline 6.3 & $\mathrm{D}$ & Pekerjaan cukup sederhana, dilakukan dengan cepat atau membutuhkan sedikit perhatian. & 0.09 \\
\hline 7.1 & $\mathrm{C}$ & Pekerjaan kompleks dan membutuhkan tingkat pemahaman dan keterampilan tinggi & 0.16 \\
\hline 7.2 & $\mathrm{D}$ & Pekerjaan cukup sederhana, dilakukan dengan cepat atau membutuhkan sedikit perhatian. & 0.09 \\
\hline 7.3 & $\mathrm{D}$ & Pekerjaan cukup sederhana, dilakukan dengan cepat atau membutuhkan sedikit perhatian. & 0.09 \\
\hline 7.4 & $\mathrm{D}$ & Pekerjaan cukup sederhana, dilakukan dengan cepat atau membutuhkan sedikit perhatian. & 0.09 \\
\hline 7.5 & $\mathrm{D}$ & Pekerjaan cukup sederhana, dilakukan dengan cepat atau membutuhkan sedikit perhatian. & 0.09 \\
\hline 7.6 & $\mathrm{D}$ & Pekerjaan cukup sederhana, dilakukan dengan cepat atau membutuhkan sedikit perhatian. & 0.09 \\
\hline 7.2 & $\mathrm{D}$ & Pekerjaan cukup sederhana, dilakukan dengan cepat atau membutuhkan sedikit perhatian. & 0.09 \\
\hline 7.3 & $\mathrm{D}$ & Pekerjaan cukup sederhana, dilakukan dengan cepat atau membutuhkan sedikit perhatian. & 0.09 \\
\hline 7.4 & $\mathrm{D}$ & Pekerjaan cukup sederhana, dilakukan dengan cepat atau membutuhkan sedikit perhatian. & 0.09 \\
\hline 7.5 & $\mathrm{D}$ & Pekerjaan cukup sederhana, dilakukan dengan cepat atau membutuhkan sedikit perhatian. & 0.09 \\
\hline 7.6 & $\mathrm{D}$ & Pekerjaan cukup sederhana, dilakukan dengan cepat atau membutuhkan sedikit perhatian. & 0.09 \\
\hline 8.1 & $\mathrm{D}$ & Pekerjaan cukup sederhana, dilakukan dengan cepat atau membutuhkan sedikit perhatian. & 0.09 \\
\hline 8.2 & $\mathrm{D}$ & Pekerjaan cukup sederhana, dilakukan dengan cepat atau membutuhkan sedikit perhatian. & 0.09 \\
\hline
\end{tabular}




\begin{tabular}{|c|c|c|c|}
\hline No & & Jenis Pekerjaan & $\begin{array}{l}\text { Generic Task } \\
\text { Unreliability }\end{array}$ \\
\hline 8.3 & $\mathrm{D}$ & Pekerjaan cukup sederhana, dilakukan dengan cepat atau membutuhkan sedikit erhatian. & 0.09 \\
\hline 9.1 & $\mathrm{D}$ & Pekerjaan cukup sederhana, dilakukan dengan cepat atau membutuhkan sedikit perhatian. & 0.09 \\
\hline 9.2 & $\mathrm{D}$ & Pekerjaan cukup sederhana, dilakukan dengan cepat atau membutuhkan sedikit perhatian. & 0.09 \\
\hline 9.3 & $\mathrm{D}$ & Pekerjaan cukup sederhana, dilakukan dengan cepat atau membutuhkan sedikit perhatian. & 0.09 \\
\hline 9.4 & $\mathrm{D}$ & Pekerjaan cukup sederhana, dilakukan dengan cepat atau membutuhkan sedikit perhatian. & 0.09 \\
\hline 9.5 & $\mathrm{D}$ & Pekerjaan cukup sederhana, dilakukan dengan cepat atau membutuhkan sedikit perhatian. & 0.09 \\
\hline 10.1 & $\mathrm{D}$ & Pekerjaan cukup sederhana, dilakukan dengan cepat atau membutuhkan sedikit perhatian. & 0.09 \\
\hline 10.2 & $\mathrm{D}$ & Pekerjaan cukup sederhana, dilakukan dengan cepat atau membutuhkan sedikit perhatian. & 0.09 \\
\hline 11.1 & $\mathrm{D}$ & Pekerjaan cukup sederhana, dilakukan dengan cepat atau membutuhkan sedikit perhatian. & 0.09 \\
\hline 11.2 & $\mathrm{D}$ & Pekerjaan cukup sederhana, dilakukan dengan cepat atau membutuhkan sedikit perhatian. & 0.09 \\
\hline 12.1 & $\mathrm{D}$ & Pekerjaan cukup sederhana, dilakukan dengan cepat atau membutuhkan sedikit perhatian. & 0.09 \\
\hline 12.2 & $\mathrm{D}$ & Pekerjaan cukup sederhana, dilakukan dengan cepat atau membutuhkan sedikit perhatian. & 0.09 \\
\hline 12.3 & $\mathrm{D}$ & Pekerjaan cukup sederhana, dilakukan dengan cepat atau membutuhkan sedikit perhatian. & 0.09 \\
\hline 13.1 & $\mathrm{D}$ & Pekerjaan cukup sederhana, dilakukan dengan cepat atau membutuhkan sedikit perhatian. & 0.09 \\
\hline 13.2 & $\mathrm{D}$ & Pekerjaan cukup sederhana, dilakukan dengan cepat atau membutuhkan sedikit perhatian. & 0.09 \\
\hline 12.3 & $\mathrm{D}$ & Pekerjaan cukup sederhana, dilakukan dengan cepat atau membutuhkan sedikit perhatian. & 0.09 \\
\hline 13.4 & $\mathrm{D}$ & Pekerjaan cukup sederhana, dilakukan dengan cepat atau membutuhkan sedikit perhatian. & 0.09 \\
\hline 13.5 & $\mathrm{D}$ & Pekerjaan cukup sederhana, dilakukan dengan cepat atau membutuhkan sedikit perhatian. & 0.09 \\
\hline 13.6 & $\mathrm{D}$ & Pekerjaan cukup sederhana, dilakukan dengan cepat atau membutuhkan sedikit perhatian. & 0.09 \\
\hline 14.1 & $\mathrm{C}$ & Pekerjaan kompleks dan membutuhkan tingkat pemahaman dan keterampilan tinggi & 0.16 \\
\hline 14.2 & $\mathrm{D}$ & Pekerjaan cukup sederhana, dilakukan dengan cepat atau membutuhkan sedikit perhatian. & 0.09 \\
\hline 14.3 & $\mathrm{D}$ & Pekerjaan cukup sederhana, dilakukan dengan cepat atau membutuhkan sedikit perhatian. & 0.09 \\
\hline 15.1 & $\mathrm{D}$ & Pekerjaan cukup sederhana, dilakukan dengan cepat atau membutuhkan sedikit perhatian. & 0.09 \\
\hline 15.2 & $\mathrm{D}$ & Pekerjaan cukup sederhana, dilakukan dengan cepat atau membutuhkan sedikit perhatian. & 0.09 \\
\hline 15.3 & $\mathrm{D}$ & Pekerjaan cukup sederhana, dilakukan dengan cepat atau membutuhkan sedikit perhatian. & 0.09 \\
\hline 16.1 & $\mathrm{C}$ & Pekerjaan kompleks dan membutuhkan tingkat pemahaman dan keterampilan tinggi & 0.16 \\
\hline 16.2 & $\mathrm{C}$ & Pekerjaan kompleks dan membutuhkan tingkat pemahaman dan keterampilan tinggi & 0.16 \\
\hline 16.3 & $\mathrm{D}$ & Pekerjaan cukup sederhana, dilakukan dengan cepat atau membutuhkan sedikit perhatian. & 0.09 \\
\hline 17.1 & $\mathrm{C}$ & Pekerjaan kompleks dan membutuhkan tingkat pemahaman dan keterampilan tinggi & 0.16 \\
\hline 17.2 & $\mathrm{D}$ & Pekerjaan cukup sederhana, dilakukan dengan cepat atau membutuhkan sedikit perhatian. & 0.09 \\
\hline 18.1 & $\mathrm{D}$ & Pekerjaan cukup sederhana, dilakukan dengan cepat atau membutuhkan sedikit perhatian. & 0.09 \\
\hline 18.2 & $\mathrm{D}$ & Pekerjaan cukup sederhana, dilakukan dengan cepat atau membutuhkan sedikit perhatian. & 0.09 \\
\hline
\end{tabular}


Tabel 3. Perhitungan nilai APOE dan HEP Lini Perakitan

\begin{tabular}{|c|c|c|c|c|c|}
\hline Task & Nilai EPC & $\begin{array}{c}\text { Assesed Proportion } \\
\text { of Effect }\end{array}$ & Assesed Effect & $\begin{array}{c}\text { Human Error } \\
\text { Probability }\end{array}$ & $\begin{array}{c}\text { Human } \\
\text { Reliability }\end{array}$ \\
\hline 1.1 & 1.2 & 0.7 & 1.14 & 0.1026 & 0.8974 \\
\hline 1.2 & 1.2 & 0.7 & 1.14 & 0.1026 & 0.8974 \\
\hline 1.3 & 1.2 & 0.7 & 1.14 & 0.1026 & 0.8974 \\
\hline 1.4 & 1.2 & 0 & 1 & 0.09 & 0.91 \\
\hline 1.5 & 1.2 & 0 & 1 & 0.09 & 0.91 \\
\hline 1.6 & 1.2 & 0 & 1 & 0.09 & 0.91 \\
\hline 1.7 & 1.2 & 0 & 1 & 0.09 & 0.91 \\
\hline 2.1 & 1.2 & 0 & 1 & 0.16 & 0.84 \\
\hline 2.2 & 1.2 & 0 & 1 & 0.16 & 0.84 \\
\hline 2.3 & 1.2 & 0 & 1 & 0.09 & 0.91 \\
\hline 2.4 & 11 & 0 & 1 & 0.09 & 0.91 \\
\hline 3.1 & 1.2 & 0 & 1 & 0.09 & 0.91 \\
\hline 3.2 & 1.2 & 0 & 1 & 0.09 & 0.91 \\
\hline 3.3 & 1.2 & 0 & 1 & 0.09 & 0.91 \\
\hline 3.4 & 1.2 & 0 & 1 & 0.09 & 0.91 \\
\hline 3.5 & 1.2 & 0.7 & 1.14 & 0.1026 & 0.8974 \\
\hline 4.1 & 1.2 & 0.7 & 1.14 & 0.1026 & 0.8974 \\
\hline 4.2 & 1.2 & 0 & 1 & 0.09 & 0.91 \\
\hline 4.3 & 1.2 & 0.7 & 1.14 & 0.1026 & 0.8974 \\
\hline 4.4 & 1.2 & 0 & 1 & 0.09 & 0.91 \\
\hline 4.5 & 1.2 & 0 & 1 & 0.09 & 0.91 \\
\hline 5.1 & 1.2 & 0.7 & 1.14 & 0.1026 & 0.8974 \\
\hline 5.2 & 1.2 & 0.7 & 1.14 & 0.1026 & 0.8974 \\
\hline 5.3 & 1.2 & 0.7 & 1.14 & 0.1026 & 0.8974 \\
\hline 5.4 & 1.2 & 0.7 & 1.14 & 0.1026 & 0.8974 \\
\hline 6.1 & 1.2 & 0 & 1 & 0.09 & 0.91 \\
\hline 6.2 & 1.2 & 0 & 1 & 0.09 & 0.91 \\
\hline 6.3 & 11 & 0 & 1 & 0.09 & 0.91 \\
\hline 7.1 & 11 & 0.7 & 8 & 1 & 0 \\
\hline 7.2 & 1.2 & 0.7 & 1.14 & 0.1026 & 0.8974 \\
\hline 7.3 & 1.2 & 0 & 1 & 0.09 & 0.91 \\
\hline 7.4 & 1.2 & 0.7 & 1.14 & 0.1026 & 0.8974 \\
\hline 7.5 & 1.2 & 0 & 1 & 0.09 & 0.91 \\
\hline 7.6 & 1.2 & 0 & 1 & 0.09 & 0.91 \\
\hline 8.1 & 1.2 & 0 & 1 & 0.09 & 0.91 \\
\hline 8.2 & 1.2 & 0 & 1 & 0.09 & 0.91 \\
\hline 8.3 & 1.2 & 0 & 1 & 0.09 & 0.91 \\
\hline 9.1 & 1.2 & 0.7 & 1.14 & 0.1026 & 0.8974 \\
\hline 9.2 & 11 & 0.7 & 8 & 0.72 & 0.28 \\
\hline 9.3 & 1.2 & 0.7 & 1.14 & 0.1026 & 0.8974 \\
\hline 9.4 & 11 & 0.7 & 8 & 0.72 & 0.28 \\
\hline
\end{tabular}




\begin{tabular}{|c|c|c|c|c|c|}
\hline Task & Nilai EPC & $\begin{array}{c}\text { Assesed Proportion } \\
\text { of Effect }\end{array}$ & Assesed Effect & $\begin{array}{c}\text { Human Error } \\
\text { Probability }\end{array}$ & $\begin{array}{c}\text { Human } \\
\text { Reliability }\end{array}$ \\
\hline 9.5 & 11 & 0.7 & 8 & 0.72 & 0.28 \\
\hline 10.1 & 1.2 & 0.7 & 1.14 & 0.1026 & 0.8974 \\
\hline 10.2 & 1.2 & 0.7 & 1.14 & 0.1026 & 0.8974 \\
\hline 11.1 & 1.2 & 0.7 & 1.14 & 0.1026 & 0.8974 \\
\hline 11.2 & 1.2 & 0 & 1 & 0.09 & 0.91 \\
\hline 12.1 & 1.2 & 0.7 & 1.14 & 0.1026 & 0.8974 \\
\hline 12.2 & 11 & 0.7 & 8 & 0.72 & 0.28 \\
\hline 12.3 & 1.2 & 0.7 & 1.14 & 0.1026 & 0.8974 \\
\hline 13.1 & 3 & 0.7 & 2.4 & 0.216 & 0.784 \\
\hline 13.2 & 11 & 0.7 & 8 & 0.72 & 0.28 \\
\hline 12.3 & 5.5 & 0.7 & 4.15 & 0.3735 & 0.6265 \\
\hline 13.4 & 11 & 0.7 & 8 & 0.72 & 0.28 \\
\hline 13.5 & 11 & 0 & 1 & 0.09 & 0.91 \\
\hline 13.6 & 11 & 0.7 & 8 & 0.72 & 0.28 \\
\hline 14.1 & 11 & 0.7 & 8 & 1 & 0 \\
\hline 14.2 & 11 & 0.7 & 8 & 0.72 & 0.28 \\
\hline 14.3 & 11 & 0.7 & 8 & 0.72 & 0.28 \\
\hline 15.1 & 11 & 0.7 & 8 & 0.72 & 0.28 \\
\hline 15.2 & 11 & 0.7 & 8 & 0.72 & 0.28 \\
\hline 15.3 & 11 & 0.7 & 8 & 0.72 & 0.28 \\
\hline 16.1 & 11 & 0.7 & 8 & 1 & 0 \\
\hline 16.2 & 6 & 0.7 & 4.5 & 0.72 & 0.28 \\
\hline 16.3 & 1.2 & 0.7 & 1.14 & 0.1026 & 0.8974 \\
\hline 17.1 & 6 & 0.6 & 4 & 0.64 & 0.36 \\
\hline 17.2 & 11 & 0 & 1 & 0.09 & 0.91 \\
\hline 18.1 & 11 & 0 & 1 & 0.09 & 0.91 \\
\hline 18.2 & 11 & 0 & 1 & 0.09 & 0.91 \\
\hline
\end{tabular}

Tabel 4. Rincian HEP $=1$

\begin{tabular}{cll}
\hline Task & \multicolumn{1}{c}{ Jenis Pekerjaan } & \multicolumn{1}{c}{ EPC'S } \\
\hline \multirow{2}{*}{7.1} & $\begin{array}{l}\text { Pekerjaan yang kompleks } \\
\text { dan membutuhkan tingkat } \\
\text { pemahaman dan } \\
\text { keterampilan tinggi }\end{array}$ & $\begin{array}{l}\text { Waktu singkat untuk } \\
\text { mendeteksi kegagalan } \\
\text { dan tindakan koreksi }\end{array}$ \\
\hline \multirow{3}{*}{14.1} & $\begin{array}{l}\text { Pekerjaan yang kompleks } \\
\text { dan membutuhkan tingkat } \\
\text { pemahaman dan } \\
\text { keterampilan tinggi }\end{array}$ & $\begin{array}{l}\text { Waktu singkat untuk } \\
\text { mendeteksi kegagalan } \\
\text { dan tindakan koreksi }\end{array}$ \\
\hline \multirow{2}{*}{16.1} & $\begin{array}{l}\text { Pekerjaan yang kompleks } \\
\text { dan membutuhkan tingkat } \\
\text { pemahaman dan } \\
\text { keterampilan tinggi }\end{array}$ & $\begin{array}{l}\text { Waktu singkat untuk } \\
\text { mendeteksi kegagalan } \\
\text { dan tindakan koreksi }\end{array}$ \\
\hline
\end{tabular}


Dari tabel perhitungan nilai HEP di atas didapatkan beberapa task yang memiliki nilai HEP $=1$ yaitu task 7.1, 14.1, dan 16.1

\section{Kesimpulan}

Dari hasil perhitungan HEP pada Tabel 4. diketahui bahwa task yang mempunyai nilai HEP $=1$ adalah task yang memiliki karakteristik pekerjaan yang kompleks dan membutuhkan tingkat pemahaman dan keterampilan yang tinggi. Adapun dari EPC's adalah task yang memiliki waktu singkat untuk mendeteksi kegagalan dan tindakan koreksi. Untuk itu penulis menyarankan untuk task tersebut maka:

a. Petugas yang mengerjakan task tersebut merupakan petugas yang telah terlatih dan telah bertugas/ menyelesaikan tingkatan tugas yang kesulitannya di bawah task tersebut (dibuktikan dengan matrix skill).

b. Penggunaan APD yang sesuai khususnya bagi task 7.1 dan 14.1 untuk melindungi dari kemungkinan tergores.

c. Pengalokasian tempat yang cukup bagi manuver petugas untuk task 16.1. Untuk menghindarkan kemungkinan terjadinya kejadian terjepit.

d. Perlunya tindakan berkelanjutan khususnya dalam pemantauan HEP misal HEP yang terbesar selanjutnya dikombinasikan dengan metode lain seperti line balancing sehingga didapatkan kondisi lini perakitan yang nyaman bagi para pekerja.

\section{Ucapan Terima Kasih}

Terima kasih kepada semua pihak yang telah mendukung sehingga penulisan jurnal ini dapat berjalan dengan lancar.

\section{Daftar Pustaka}

Agus, W., Choirul, B.,(2015), Aplikasi Human Reliability Assessment sebagai upaya peningkatan kualitas produk batik, Simposium Nasional Teknologi Terapan (SNTT)

Amin, B.P., Ehsanollah, H., (2015), The comparative study of evaluating human error assessment and reduction technique and cognitive reliability and error analysis method techniques in the control room of the cement industry, International Journal of Environmental Health Engineering | Vol. 4 • Issue 1 | January-March 2015

Barry, K., (1995). The validation of three Human Reliability Quantification techniques - THERP, HEART and JHEDI: Part 1 - technique descriptions and validation issues, Applied Ergonomic.s Vol 27. No. h. pp. W\&.173. IWh

Bell. Julie \& Holroyd, J., (2009). Review of Human Reliability Assesment Methods. Health and Safety Laboratory Harpur Hill Buxton Derbyshire

Dian, M. S., Ayu, R. A., Nataya, C. R., (2015), Human Reliability Assessment dengan Metode Human
Error Assessment and Reduction Technique pada Operator Stasiun Shroud PT. X, Jurnal Rekayasa Sistem Industri Vol. 4, No. 1, 2015

Evica, S., Bojan, B., Marko, C.,(2017), APPLICATION OF HEART TECHNIQUE FOR HUMAN RELIABILITY ASSESSMENT - A SERBIAN EXPERIENCE, FACTA UNIVERSITATIS Series: Working and Living Environmental Protection Vol. 14, No 3, 2017, pp. 187 - 196 https://doi.org/10.22190/FUWLEP1703187S

Francesco,C., Mariarosa, G., Elio, T.,(2014), THERP and HEART integrated methodology for human error assessment, Radiation Physics and Chemistry 116(2015)262-266

Ludfi, P.B., Masao, F., (2018), Human Error Assessment and Reduction Technique for Marine Accident Analysis: The Case of Ship Grounding, Transactions of Navigation Vol.3 No.1, 2018

Mark Evans, Ying He *, Leandros Maglaras, Helge Janicke, 2018, HEART-IS: A novel technique for evaluating human error-related information security incidents, c o m p u t e r s \& s e c u r i t y 80 (2019)74-89

Riselvia, N., Isa, M., Ragil, I. H., (2017), Penilaian Human Error Probabilitydengan Metode Human Error Assessment and Reduction Technique (HEART)

(Studi di Departemen FinishingPT. Eratex Djaja, Tbk), e-Jurnal Pustaka Kesehatan, vol. 5, (no.3), September, 2017

Saida, M., Yayan H., dan Ade, S.M., (2013), Analisa Tingkat Keandalan Operator Inside Welding dengan Metode Human Error Assessment and Reduction Technique, Jurnal Teknik Industri, Vol.1, No.3, September 2013, pp.245-250 ISSN 2302-495X

Sarbjeet, S.,, Rupesh, K.,(2015), Evaluation of human error probability of disc brake unit assembly and wheel set maintenance of Railway Bogie, 6th International Conference on Applied Human Factors and Ergonomics (AHFE 2015) and the Affiliated Conferences, AHFE 2015, Procedia Manufacturing 3 ( 2015 ) $3041-3048$

Shofiana, I., Rina, S.,Vivin, S., Analisis Probabilitas Human Error Pada Pekerjaan Penggantian Bola Ball Mill Dengan Metode HEART Di SAG Mill Concentrating (Studi Kasus: Perusahaan Pertambangan), Proceeding 1st Conference on Safety Engineering and Its Application ISSN No. $2581-2653$

Tiara, R., Elisabeth, G., dan Buchari., (2013), Analisa Human Error dengan Metode SHERPA dan HEART pada kecelakaan kerja di PT xyz, $e$ Jurnal Teknik Industri FT USU Vol 2, No. 1, Mei 2013 pp. 58-65 
Weizhong, W., Xinwang, L., Yong, Q., (2017), A modified HEART method with FANP for human error assessment in highspeed railway dispatching tasks, International Journal of Industrial Ergonomics 67 (2018) 242-258
Wolfgang, P., Mario, H., (2012), Human error probabilities from operational experience of German nuclear power plants, Reliability Engineering and System Safety 109 (2013) 150159 